$1-1-1962$

\title{
The Effects of antibiotics on Vibrio fetus and the metabolism of Bovine spermatozoa
}

G. R. Grench

Follow this and additional works at: https://researchrepository.wvu.edu/ wv_agricultural_and_forestry_experiment_station_bulletins

\section{Digital Commons Citation}

Grench, G. R., "The Effects of antibiotics on Vibrio fetus and the metabolism of Bovine spermatozoa" (1962). West Virginia Agricultural and Forestry Experiment Station Bulletins. 471T.

https://researchrepository.wvu.edu/wv_agricultural_and_forestry_experiment_station_bulletins/651 @ WVU. It has been accepted for inclusion in West Virginia Agricultural and Forestry Experiment Station Bulletins by an authorized administrator of The Research Repository @ WVU. For more information, please contact ian.harmon@mail.wvu.edu. 

Digitized by the Internet Archive in 2010 with funding from

Lyrasis Members and Sloan Foundation 
The Effects of Antibiotics on Vibrio Fetus and the Metabolism of Bovine Spermatozoa

\section{WEST VIRGINIA UNIVERSITY AGRICULTURAL EXPERIMENT STATION}




\section{THE AUTHORS}

G. R. French, who is now residing at Fort Detrick, Maryland, was formerly a graduate student at West Virginia University. Charles Norman is Dairy Scientist at the West Virginia University Agricultural Experiment Station. R. S. Dunbar, JR., is Statistician at the West Virginia University Agricultural Experiment Station. I. D. Porterfield is Dairy Scientist at the West Virginia University Agricultural Experiment Station.

\section{ACKNOWLEDGMENT}

Data presented in this Technical Bulletin are from a thesis submitted by G. R. French to the Graduate School of West Virginia University in partial fulfillment of the requirements for the degree of Master of Science, 1958.

West Virginia UNIVERSITY

Agricultural Experiment Station

College of Agriculture, Forfstry, and Home Economics

A. H. Vanlandingham, Director 


\section{The Effects of Antibiotics on Vibrio Fetus and the Metabolism of Bovine Spermatozoa}

\section{Introduction}

G. R. FRENCH, C. NORMAN, R. S. DUNBAR, JR., and I. D. PORTERFIELD

TIBRIO FETUS, the causative agent of vibrionic abortion and epizootic sterility, presents a serious problem to the breeder of beef and dairy cattle. With the advent of artificial insemination, and particularly the use of frozen semen, the problem has increased in importance because of the greater possibility of spreading the disease.

In recent years, people working with artificial insemination have become increasingly aware of this problem. It has been found that two antibiotics, penicillin and dihydrostreptomycin sulphate, are satisfactory agents for use in preventing spread of the clisease when warm semen $\left(5^{\circ}\right.$ C. $)$ is used for artificial insemination. However, it has been definitely established that these agents are ineffective in frozen semen (Hughes and Gilman 8). Frozen semen is becoming increasingly important in the field of artificial insemination because it can be stored for much longer periods of time and shipped greater distances for wider distribution. Hence, the inability to control the disease in frozen semen is a major problem.

The purpose of this work was to test in vitro the existing antibiotics or antibiotic agents in an attempt to find one bactericidal to Vibrio fetus and suitable for use in frozen semen. The problem was divided into three parts:

I. Determination of the relative effects of antibiotics against Vibrio fetus.

II. Determination of the relative effects of these agents on spermatozoa.

III. Determination of the effectiveness of these agents in frozen semen artificially inoculated with Vibrio fetus.

This report is a summary of results obtained from experiments conducted in the three areas. Each antibiotic agent was studied in conjunction with 26 strains of Vibrio fetus. Approximately half of these 
strains were found to be resistant to all agents tested; therefore, results will be given in many instances for both sensitive and resistant strains.

Vibrio fetus was found to grow successfully in Albimi-brucella media when incubated at $37^{\circ}$ C. under 63 per cent illuminating gas and 37 per cent air to give a final oxygen content of approximately 7 per cent. Plate counts were made on Albimi-brucella agar fortified with 5-10 per cent whole human blood and 0.75 per cent agar incubated under the above conditions.

Manufacturers of the antibiotics used in this study are identified in the Appendix.

\section{Review of Literature}

Little was known about transmission of the disease until 1950 when Stegena (17) reported isolation of the organism from untreated semen. In 1951, Terpstra (18) called the bull the primary route of transmission. Later work by Easterbrooks and Plastridge (5) showed that the infectious agent could be transmitted via artificial insemination, and confirmed transmission by infected semen and physical contact with the infected bull.

Prier (15) was the first worker to report on extensive tests of antibiotics against Vibrio fetus. Minimum levels of penicillin, streptomycin sulphate, Aureomycin, bacitracin, Chloromycetin, neomycin sulphate, and Terramycin which would inhibit growth of Vibrio fetus in thiol media were determined. Prier found Chloromycetin, neomycin sulphate and Terramycin to be the more effective inhibitors. Unfortunately, his results may be misleading because thiol media is designed to inactivate certain antibiotics, but has no effect on others.

Plastridge and Easterbrooks (14) did further work on antibiotics in thiol media. While $500 \mu \mathrm{g} . / \mathrm{ml}$. streptomycin sulphate prevented growth, 6,000 units $/ \mathrm{ml}$. of penicillin, $1,000 \mu \mathrm{g} . / \mathrm{ml}$. of Aureomycin and Terramycin, $640 \mu \mathrm{g} . / \mathrm{ml}$. of polymyxin, $1,600 \mu \mathrm{g} . / \mathrm{ml}$. of bacitracin, gramicidin, and tyrothricin failed to prevent growth after prolonged incubation at $37^{\circ} \mathrm{C}$.

Orthey and Gilman (12) found 500 units of penicillin combined with $500 \mu \mathrm{g} . / \mathrm{ml}$. streptomycin sulphate and 0.03 per cent sulfanilamide was effective against all strains of Vibrio fetus in concentrations found in infected semen (4 to 11 million $/ \mathrm{ml}$.). This work was done with egg yolk citrate extender at $5^{\circ} \mathrm{C}$.

While much of the work has been directed towards the establishment of minimum inhibition levels, some workers have investigated the 
bactericidal effects of these agents. DiLullo, Poelma and Faber

tested antibiotics for their bactericidal effect. The organism was exposed to various antibiotics for a known duration at $5^{\circ} \mathrm{C}$. in a skim milk extender. After the exposure period the organism was washed free of the antibiotics by centrifuging in saline solution at $3,500 \mathrm{rpm}$. Pertinent results were summarized as follows: they found $500 \mu \mathrm{g} . / \mathrm{ml}$. streptomycin sulphate, and $500 \mu \mathrm{g} . / \mathrm{ml}$. neomycin sulphate required eight hours to destroy the organism with the exception of one strain. Polymyxin B, Aureomycin, and Terramycin were found to be ineffective.

While antibiotics were being tested against the organism, considerable other work was completed concerning the effects of these agents on bovine spermatozoa. In 1948, Almquist, Thorp, and Knodt (1) reported on the effect of penicillin upon the livability, glycolysis and bacterial content of semen. They found 750 units of penicillin did not affect motility of semen stored at $4.5^{\circ} \mathrm{C}$. All levels of the antibiotic depressed utilization of glucose, and suppressed bacterial growth. Levels of 1,000 and 2,000 units/ml. adversely affected motility.

Later in 1948, Almquist, Glantz, and Thorp (2) completed work on the effect of streptomycin sulphate upon the livability of spermatozoa and the bacterial content of semen. They found streptomycin sulphate did not affect livability of spermatozoa at levels up to $1,000 \mu \mathrm{g} . / \mathrm{ml}$., and levels above $100 \mu \mathrm{g} . / \mathrm{ml}$. proved very effective in inhibiting bacterial growth.

In a comparison of the effects of sulfanilamide, penicillin, streptomycin sulphate, and polymyxin upon fertility, Foote and Bratton (7) showed polymyxin to be less effective than penicillin and streptomycin sulphate, and about equal to sulfanilamide.

Sykes and Mixner (16) established optimum and toxic levels of Aureomycin, dihydrostreptomycin sulphate, Chloromycetin, and penicillin on the basis of motility. Aureomycin was shown to be toxic at relatively low concentrations.

In 1953, Dunn (4) found that 0.03 per cent sulfanilamide in frozen semen reduced motile spermatozoa 29 to 43 per cent. DiLullo et al. (3), in 1957, determined the optimum levels of several antibiotics on motility. This work was based on longer periods of time than any of the previous above work using the same methods. These workers found $500 \mu \mathrm{g} . / \mathrm{ml}$. of neomycin sulphate, $250 \mu \mathrm{g} . / \mathrm{ml}$. Chloromycetin and streptomycin sulphate, $500 \mu \mathrm{g} . / \mathrm{ml}$. of dihydrostreptomycin sulphate, 500 units of penicillin, and $100 \mu \mathrm{g} . / \mathrm{ml}$. of polymyxin to be optimum levels. Two thousand $\mu \mathrm{g} . / \mathrm{ml}$. of dihydrostreptomycin sulphate and $125 \mu \mathrm{g} . / \mathrm{ml}$. of Terramycin and Aureomycin were toxic to spermatozoa. 
In the use of semen stored at $5^{\circ}$ C. for artificial insemination, 500 $\mu \mathrm{g} / \mathrm{ml}$. of streptomycin sulphate and 500 units of penicillin appear to be satisfactory agents against Vibrio fetus. Orthey and Gilman (12) found the above agents effective against concentrations of Vibrio fetus as high as 2.25 million organisms $/ \mathrm{ml}$. When semen is frozen, however, the antibiotics are apparently ineffective. Hughes and Gilman (8) recovered Vibrio fetus from thawed ampoules of frozen semen treated with the above antibiotics. Again in 1954, MacPherson and Fish (10) rerecovered Vibrio fetus from frozen semen treated with 1,000 units of penicillin and $500 \mu \mathrm{g} . / \mathrm{ml}$. of streptomycin sulphate. In 1955, Hughes and Gilman (8) concluded that glycerol present in frozen semen was interfering with streptomycin sulphate, the principal anti-vibrio agent.

\section{Experimental Results}

I. THE EFFEGTS OF ANTIBIOTIC AGENTS ON VIBRIO FETUS Experiment A: Determining Inhibition Levels. Agents Tested

erythromycin

Chloromycetin

neomycin sulphate

Salmotin

nitrofuran compound \#6 (anti.)

nitrofuran compound \#180

nitrofuran compound $\# 246$

brilliant green dye

Aureomycin
Terramycin
Panmycin
thiosterpton
bacitracin
oxymycin
Cathomycin
polymyxin B

This experiment was designed to determine maximum levels of antibiotics tolerated by sensitive and resistant strains of Vibrio fetus and the minimum level required to inhibit growth of these strains for 14 days at $37^{\circ}$ C. Each antibiotic was tested against a standard loopful of 24hour Vibrio fetus inoculum in $5 \mathrm{ml}$. of Albimi-brucella media containing 0.075 per cent agar (semi-solid). The results of this experiment are shown in Table 1. Presented are data for both sensitive and resistani strains. The groupings were based on the sensitivity of each strain of Panmycin. Those strains whose growth was inhibited by $25 \mu \mathrm{g} . / \mathrm{ml}$. or less of Panmycin were considered sensitive. Those strains whose inhibition required more than $25 \mu \mathrm{g} . / \mathrm{ml}$. were considered resistant. Therefore, the results given in Table 1 are not absolute for each strain in either group; i.e., all strains may not tolerate maximum level given, and may be resistant to less than the minimum doses indicated for inhibition. This grouping was made possible and seemed desirable in that all strains 
Table 1. Tolerated and Inhibitive Levels of Antibiotics Against Vibrio fetus (Tested in Albimi-brucella Media Incubated at $37^{\circ} \mathrm{C}$. for 14 Days Under 7 Per Gent Oxygen)

\begin{tabular}{|c|c|c|c|c|}
\hline \multirow[t]{4}{*}{ AGENT } & \multicolumn{2}{|c|}{ Sensitive Strains } & \multicolumn{2}{|c|}{ REsistant Strains } \\
\hline & Maximum & Minimum & Maximum & Minimum \\
\hline & Tolerated & Inhibitive & Tolerated & Inhibitive \\
\hline & $\mu g . / m l$ & $\mu g . / m l$ & $\mu g . / \mathrm{ml}$ & $\mu g . / m l$ \\
\hline Panmycin & 10.0 & 25.0 & 35.0 & 40.0 \\
\hline Chloromycetin & 2.5 & 5.0 & 15.0 & 17.5 \\
\hline Salmotin* & 0.2 & 0.5 & 17.5 & 20.0 \\
\hline neomycin sulphate .... & 2.5 & 5.0 & 2.5 & 5.0 \\
\hline N. F. \#180** & 0.1 & 0.2 & 0.8 & 1.0 \\
\hline N. F. $\$ 246$ & 0.5 & 1.0 & 2.0 & 3.0 \\
\hline N. F. ${ }^{\pi} 6$ & 1.0 & 2.5 & 2.5 & 5.0 \\
\hline brilliant green dye .... & 7.5 & 10.0 & 500.0 & $\mathrm{a}$ \\
\hline Aureomycin & 150.0 & $\mathrm{a}$ & 一 & 一 \\
\hline Terramycin & 150.0 & $\mathrm{a}$ & 一 & 一 \\
\hline thiostrepton ..................... & 50.0 & a & - & 一 \\
\hline novobiocin & 50.0 & $\mathrm{a}$ & - & 一 \\
\hline bacitracin ...................... & 500.0 & a & - & 一 \\
\hline oxmycin & 50.0 & a & - & - \\
\hline Cathomycin & 50.0 & $\mathrm{a}$ & - & 一 \\
\hline
\end{tabular}

*units/ml., 215 units/mg.

**nitrofuran

a - mnd-minimum inhibitive level not determined.

were found to be either sensitive or resistant to all antibiotics tested though not necessarily to the same degree.

The results of this experiment indicate Panmycin, neomycin sulphate, Salmotin, Chloromycetin and the three nitrofuran compounds remained stable under prolonged incubation, and were effective agents against both sensitive and resistant strains. Neomycin sulphate was perhaps the most effective agent in that the same low level of $5 \mu \mathrm{g} . / \mathrm{ml}$. inhibited both sensitive and resistant strains. Salmotin showed the widest range; a 40-fold increase of the sensitive strain level was required to inhibit resistant strains. Aureomycin and Terramycin were effective for short periods of time, but did not remain stable under prolonged periods of incubation. Brilliant green dye was effective against sensitive strains, but was ineffective against resistant strains. Thiostrepton, novobiocin, bacitracin, oxymycin, and Cathomycin were found to be ineffective against all strains.

Experiment B. Determination of Bactericidal Effect.

Panmycin

Agents Tested

Chloromycetin

neomycin sulphate
Levels Tested 40, $75 \mu \mathrm{g} . / \mathrm{ml}$. $17.5,250 \mu \mathrm{g} . / \mathrm{ml}$. $5,500 \mu \mathrm{g} \cdot / \mathrm{ml}$. 
Salmotin

nitrofuran compound \#6 (anti.)

nitrofuran compound $\# 180$

nitrofuran compound $\# 246$

dihydrostreptomycin sulphate
20, 75 units $/ \mathrm{ml}$.

$5,15 \mu \mathrm{g} . / \mathrm{ml}$.

$1,3 \mu \mathrm{g} . / \mathrm{mI}$.

3, $9 \mu \mathrm{g} . / \mathrm{ml}$.

$500 \mu \mathrm{g} . / \mathrm{ml}$.

All agents were tested against the same resistant strain of Vibrio fetus. Levels tested were determined from Experiment A just described and by testing against bovine spermatozoa as described later in this report.

Antibiotics were incubated in $5 \mathrm{ml}$. of Albimi-brucella semi-solid media containing $0.2 \mathrm{cc}$. of a Vibrio fetus suspension $(1.25 \times 109$ organisms $/ \mathrm{ml}$.) and $0.5 \mathrm{cc}$. of antibiotic diluted in saline. Sample tubes were drawn for culture at 2, 4, 6, 12, 18, 24, 48, and 96 hours. At the end of the described incubation period, two tubes for each antibiotic were tested by sedimenting the organisms present, washing them twice with sterile saline to remove the antibiotic, then transferring them to two Albimi-brucella blood agar plates and two tubes of Albimi-brucella semi-solid media. The sub-cultures were then incubated for 96 hours in 7 per cent oxygen at $37^{\circ} \mathrm{C}$.

The data obtained from this experiment are presented in Table 2. Panmycin, Chloromycetin and Salmotin did not kill the organisms at the low level within the 96-hour maximum period of exposure. At the high level all three required the full 96 hours to kill the organisms. Neomycin sulphate at the $500 \mu \mathrm{g} . / \mathrm{ml}$. level destroyed all organisms in 12 hours and proved more effective than dihydrostreptomycin which consistently required 18 hours to kill. The nitrofuran compounds would kill all organisms in 18 hours, but were less effective than dihydrostreptomycin at the 12-hour period.

\section{THE EFFECT OF ANTIBIOTIC AGENTS ON BOVINE SPERMATOZOA}

Experiment A: Determining Maximum Levels of Antibiotic AgENTS.

\begin{tabular}{ll}
\multicolumn{1}{c}{ Agents Tested } & \multicolumn{1}{c}{ Levels Tested } \\
Panmycin & $40,75,125,250 \mu \mathrm{g} \cdot / \mathrm{ml}$. \\
Chloromycetin & $17.5,125,250,400 \mu \mathrm{g} \cdot / \mathrm{ml}$. \\
neomycin sulphate & $5,50,250,500 \mu \mathrm{g} \cdot / \mathrm{ml}$. \\
Salmotin & $20,75,125,250 \mu \mathrm{g} \cdot / \mathrm{ml}$. \\
nitrofuran compound \#6 (anti.) & $5,15,20,30 \mu \mathrm{g} \cdot / \mathrm{ml}$. \\
nitrofuran compound \#180 & $1,3,5,10 \mu \mathrm{g} \cdot / \mathrm{ml}$. \\
nitrofuran compound \#246 & $3,9,15,30 \mu \mathrm{g} \cdot / \mathrm{ml}$. \\
dihydrostreptomycin sulphate & $500 \mu \mathrm{g} \cdot / \mathrm{ml}$. \\
streptomycin sulphate & $500 \mu \mathrm{g} \cdot / \mathrm{ml}$.
\end{tabular}


Table 2. Time Required to Destroy Vibrio fetus at $37^{\circ} \mathrm{C}$. (Tested in Albimi-brucella Media Incubated at $37^{\circ}$ C. Under 7 Per Cent Oxygen)

\begin{tabular}{|c|c|c|}
\hline $\begin{array}{c}\text { AGENT AND LEVEL, } \\
\mu \mathrm{g} / \mathrm{ml} \text {. }\end{array}$ & $\begin{array}{l}\text { Maximum Time } \\
\text { Tolerated (Hr.) }\end{array}$ & $\begin{array}{l}\text { Minimum Time } \\
\left.\text { To Destroy ( } \mathrm{Hr}^{2}\right)\end{array}$ \\
\hline \multicolumn{3}{|l|}{ Panmycin } \\
\hline 40 & 96 & a \\
\hline 75 & 48 & 96 \\
\hline \multicolumn{3}{|l|}{ Chloromycetin } \\
\hline $17.5 \quad \ldots$ & 96 & a \\
\hline 250 & 48 & 96 \\
\hline \multicolumn{3}{|l|}{ Salmotin* } \\
\hline 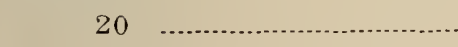 & 96 & $\mathrm{a}$ \\
\hline 75 & 48 & 96 \\
\hline \multicolumn{3}{|l|}{ neomycin sulphate } \\
\hline 5 & 96 & $\mathrm{a}$ \\
\hline 500 & 6 & 12 \\
\hline \multicolumn{3}{|l|}{ dihydrostreptonzycin sulphate } \\
\hline 500 & 12 & 18 \\
\hline \multicolumn{3}{|l|}{ nitrofuran $\sharp 6$} \\
\hline $5 \quad \ldots \ldots$ & 18 & 24 \\
\hline 15 & 12 & 18 \\
\hline \multicolumn{3}{|l|}{ nitrofuran $\sharp 180$} \\
\hline 1 & 18 & 24 \\
\hline 3 & 12 & 18 \\
\hline \multicolumn{3}{|l|}{ nitrofuran $\#^{2} \pm 6$} \\
\hline $3 \quad \pi$ & 18 & 24 \\
\hline … & 12 & 18 \\
\hline
\end{tabular}

$*$ units $/ \mathrm{ml}$.

a - mnd-minimum time to destroy not determined.

Serial dilution of the above agents was made in Krebs-Ringer phosphate-buffer solution, hereafter referred to as KRB. One-half $\mathrm{ml}$. of bovine spermatozoa obtained from a pooled sample of semen from one Ayrshire and one Jersey bull was added to $2.5 \mathrm{ml}$. of the antibiotic-KRB solution and incubated at $37^{\circ} \mathrm{C}$. for three hours in a constant temperature water bath. At the end of this period, spermatozoa of experimental and control groups were checked for motility and percentage of live spermatozoa.

Motility was a relative comparison based on six standards of progressive motility: excellent, very good, good, fair, poor, and immotility. These six standards were assigned numerical values of five to zero respectively. Live-dead slides were prepared by adding one drop of spermatozoa to five drops of eosin-nigrosine stain on a glass slide. The stain and spermatozoa were then thoroughly mixed with a wooden toothpick and allowed to stand five minutes. A second glass slide was used to smear the mixture over the entire slide at the end of the five-minute period. Individual sperm that appeared partially or totally pink microscopically were considered dead. One thousand spermatozoa were counted on each slide. Slides were prepared in duplicate for each sample. 
The results of this experiment are shown in Table 3. For comparative purposes, dihydrostreptomycin and streptomycin sulphate were tested at $500 \mu \mathrm{g} . / \mathrm{ml}$. These two agents had no detectable effect on sperm motility and viability at this concentration for the three-hour period.

Table 3. The Effect of Serial Dilutions of Antibiotic Agents on Motility and Per Cent Live Bovine Spermatozoa*

\begin{tabular}{|c|c|c|c|}
\hline AGENT & $\begin{array}{l}\text { LEveL } \\
\mu \mathrm{g} . / \mathrm{ml} \text {. }\end{array}$ & $\begin{array}{l}\text { MotILITY } \\
(\text { CODED }) * *\end{array}$ & $\begin{array}{c}\text { Per Cent } \\
\text { Live }\end{array}$ \\
\hline Panmycin & $\begin{array}{c}40 \\
75 \\
125 \\
250 \\
\text { control }\end{array}$ & $\begin{array}{l}3.0 \\
3.0 \\
2.0 \\
1.0 \\
3.0\end{array}$ & \begin{tabular}{l|}
38.1 \\
38.1 \\
27.6 \\
11.0 \\
38.0
\end{tabular} \\
\hline Chloromycetin & $\begin{array}{c}17.5 \\
125 \\
250 \\
500 \\
\text { control }\end{array}$ & $\begin{array}{l}3.0 \\
3.0 \\
3.0 \\
3.0 \\
3.0\end{array}$ & \begin{tabular}{l|l|}
37.8 & \\
37.3 & \\
37.6 & \\
36.1 & \\
39.7 &
\end{tabular} \\
\hline neomycin sulphate & $\begin{array}{c}5 \\
50 \\
250 \\
500 \\
\text { control }\end{array}$ & $\begin{array}{l}4.0 \\
4.0 \\
3.0 \\
3.0 \\
3.0\end{array}$ & $\begin{array}{l}39.9 \\
38.3 \\
38.9 \\
38.2 \\
38.0\end{array}$ \\
\hline $\begin{array}{l}\text { Salmotin } \\
\text { units } / \mathrm{ml} \text {. } \\
219 / \mathrm{mg}\end{array}$ & $\begin{array}{c}20 \\
75 \\
125 \\
250 \\
\text { control }\end{array}$ & $\begin{array}{r}3.0 \\
3.0 \\
1.0 \\
0 \\
3.0\end{array}$ & $\begin{array}{r}38.5 \\
38.1 \\
10.6 \\
0.0 \\
38.0\end{array}$ \\
\hline nitrofuran $\#^{6}$ (anti.) & $\begin{array}{c}5 \\
15 \\
20 \\
30 \\
\text { control }\end{array}$ & $\begin{array}{r}4.0 \\
3.0 \\
2.0 \\
0 \\
3.0\end{array}$ & \begin{tabular}{l|}
39.7 \\
39.3 \\
27.3 \\
11.9 \\
38.0
\end{tabular} \\
\hline nitrofuran $\# 180$ & $\begin{array}{c}1 \\
3 \\
5 \\
10 \\
\text { control }\end{array}$ & $\begin{array}{l}3.0 \\
3.0 \\
2.0 \\
1.0 \\
3.0\end{array}$ & $\begin{array}{l}38.8 \\
39.5 \\
38.6 \\
11.9 \\
39.7\end{array}$ \\
\hline nitrofuran $\# 246$ & $\begin{array}{c}3 \\
9 \\
15 \\
30 \\
\text { control }\end{array}$ & $\begin{array}{l}4.0 \\
3.0 \\
2.0 \\
1.0 \\
3.0\end{array}$ & \begin{tabular}{r|}
40.1 \\
38.8 \\
31.1 \\
9.3 \\
39.7
\end{tabular} \\
\hline dihydrostreptomycin sulphate & $\begin{array}{c}500 \\
\text { control }\end{array}$ & $\begin{array}{l}3.0 \\
3.0\end{array}$ & $\begin{array}{l}39.3 \\
39.7\end{array}$ \\
\hline streptomycin sulphate & $\begin{array}{c}500 \\
\text { control }\end{array}$ & $\begin{array}{l}3.0 \\
3.0\end{array}$ & $\begin{array}{l}38.8 \\
39.7\end{array}$ \\
\hline
\end{tabular}

* Semen was diluted in $\mathrm{KRB}$ and incubated at $37^{\circ}$ C. for 3 hours.

* Code for motility: 5-Excellent progressire: 4-Very good progressive; 3-Good progressive; 2-Fair progressive; 1-Poor progressive; O-Immotile. 
Chloromycetin had no effect on sperm recovery and survival at the $500 \mu \mathrm{g} . / \mathrm{ml}$; however, the results of DiLullo et al. (3) were used in further experiments on this agent as they were based on longer periods of time. They found $250 \mu \mathrm{g} . / \mathrm{ml}$. to be the optimum amount of Chloromycetin to be used in semen. Salmotin and Panmycin could be used at the 75 -unit and $75-\mu \mathrm{g} . / \mathrm{ml}$. levels, but showed a slight effect at a concentration of 100 units and $100 \mu \mathrm{g} . / \mathrm{ml}$. respectively. Neomycin sulphate showed no effect at the maximum $500 \mu \mathrm{g} . / \mathrm{ml}$. level. Higher concentrations were not tested because the work of DiLullo indicated they were toxic. Nitrofuran \#6 (anti.) showed no effect at a concentration of $15 \mu \mathrm{g} . / \mathrm{ml}$. level, but clid show an adverse effect at the $20 \mu \mathrm{g} . / \mathrm{ml}$. level. Nitrofurans \#180 and \#246 could be used at maximum doses of 3 and 9 $\mu \mathrm{g} . / \mathrm{ml}$. respectively.

\section{Experiment B: Determination of Oxygen Consumption, Motility and Per Gent Live Spermatozoa.}

Concentrations to be tested in this experiment were based on Experiment A and levels of inhibition for Vibrio fetus. On the basis of DiLullo's work, dihydrostreptomycin sulphate, streptomycin sulphate and neomycin sulphate at the $500 \mu \mathrm{g}$./ $\mathrm{ml}$. level and Chloromycetin at the $250 \mu \mathrm{g} . / \mathrm{ml}$. level were also included in the study. Occasionally higher than indicated amounts were tested for several agents to compare the results of obvious toxic concentrations to sub-toxic concentrations.

Agents Tested

Panmycin

Chloromycetin

neomycin sulphate

Salmotin

dihydrostreptomycin sulphate

streptomycin sulphate

nitrofuran compound \#6 (anti.)

nitrofuran compound $\# 180$

nitrofuran compound \#246

brilliant green dye
Levels Tested $40,75,125 \mu \mathrm{g} \cdot / \mathrm{ml}$.

$17.5,250 \mu \mathrm{g} . / \mathrm{ml}$.

$5,500 \mu \mathrm{g} . / \mathrm{ml}$.

20,75 units $/ \mathrm{ml}$.

$500 \mu \mathrm{g} . / \mathrm{ml}$.

$500 \mu \mathrm{g} \cdot / \mathrm{ml}$.

$5,15,50 \mu \mathrm{g} \cdot / \mathrm{ml}$.

$1,3,5 \mu \mathrm{g} \cdot / \mathrm{ml}$.

$3,9,15 \mu \mathrm{g} . / \mathrm{ml}$.

$100 \mu \mathrm{g} . / \mathrm{ml}$.

Oxygen consumption was determined by the usual Warburg techniques. The automatic shaker was set at 120 oscillations/minute and a constant temperature of $37^{\circ} \mathrm{C}$. was maintained. Both single and double sidearm flasks were used in this experiment. Two-tenths $\mathrm{ml}$. of 20 per cent potassium hydroxide was used in the center well as the carbon dioxide absorbent.

One-half $\mathrm{ml}$. of the antibiotic solution was pipetted into the sidearm of the flask. One-half $\mathrm{ml}$. of semen was added to $2.0 \mathrm{ml}$. of $\mathrm{KRB}$ 
in the bottom of the flask. Density of the semen was determined turbidimetically by the Klett photoelectric apparatus. A control was set up using $1 / 2 \mathrm{ml}$. of $\mathrm{KRB}$ in the sidearm in place of the antibiotic solution. Additional controls were found necessary for Salmotin and Panmycin because they were found to take up oxygen. Contents of the sidearms for all flasks were tipped after a 30-minute equilibration period. Manometers were read every 15 minutes for three hours.

Motility and per cent live spermatozoa were observed for each flask, both experimental and control, at the end of the three-hour observation period. Methods for observing per cent live spermatozoa and motility were identical with those of Experiment A of this section.

The results of this experiment are summarized in Table 4. Detailed data obtained from this experiment are not included in this report as they are too voluminous. (Observed data, including a statistical analysis, are reported in the thesis.)

Table 4. Summary of Experiment B: Oxygen Consumption, Motility, Per Cent Live Spermatozoa

\begin{tabular}{|c|c|c|c|c|c|c|c|c|c|}
\hline \multirow{2}{*}{$\begin{array}{l}\text { TEST Conducted } \\
\text { Panmycin* } \\
\text { Level of Agent }\end{array}$} & \multicolumn{3}{|c|}{$\begin{array}{c}\text { OXYGEN } \\
\text { CONSUMPTION }\end{array}$} & \multicolumn{3}{|c|}{ Motility } & \multicolumn{3}{|c|}{$\begin{array}{c}\text { Per Cent Live } \\
\text { Spermatozoa }\end{array}$} \\
\hline & $\begin{array}{l}-1 \\
40^{* *}\end{array}$ & $\begin{array}{r}-2 \\
75\end{array}$ & $\begin{array}{r}-2 \\
125\end{array}$ & $\begin{array}{c}0 \\
40\end{array}$ & $\begin{array}{l}-1 \\
75\end{array}$ & $\begin{array}{c}-1 \\
125\end{array}$ & $\begin{array}{r}0 \\
40\end{array}$ & $\begin{array}{r}+1 \\
75\end{array}$ & $\begin{array}{r}-1 \\
125\end{array}$ \\
\hline $\begin{array}{l}\text { Chloromycetin } \\
\text { Level of Agent }\end{array}$ & $\begin{array}{c}0 \\
17.5 \\
\end{array}$ & $\begin{array}{r}-2 \\
250 \\
\end{array}$ & & $\begin{array}{c}0 \\
17.5\end{array}$ & $\begin{array}{r}0 \\
250 \\
\end{array}$ & & $\begin{array}{c}0 \\
17.5\end{array}$ & $\begin{array}{r}0 \\
250\end{array}$ & \\
\hline $\begin{array}{l}\text { neomycin } \\
\text { Level of Agent }\end{array}$ & $\begin{array}{r}+2 \\
5\end{array}$ & $\begin{array}{l}+1 \\
500 \\
\end{array}$ & & $\begin{array}{l}0 \\
5\end{array}$ & $\begin{array}{r}0 \\
500\end{array}$ & & $\begin{array}{l}0 \\
5\end{array}$ & $\begin{array}{r}0 \\
500 \\
\end{array}$ & \\
\hline $\begin{array}{l}\text { Salmotin } \\
\text { Level of Agent }\end{array}$ & $\begin{array}{r}0 \\
20\end{array}$ & $\begin{array}{r}+1 \\
75\end{array}$ & & $\begin{array}{r}0 \\
20\end{array}$ & $\begin{array}{r}0 \\
75\end{array}$ & & $\begin{array}{r}0 \\
20\end{array}$ & $\begin{array}{r}+1 \\
75\end{array}$ & \\
\hline $\begin{array}{l}\text { dihydrostreptomycin } \\
\text { Level of Agent }\end{array}$ & $\begin{array}{r}0 \\
500 \\
\end{array}$ & & & $\begin{array}{r}0 \\
500\end{array}$ & & & $\begin{array}{r}0 \\
500\end{array}$ & & \\
\hline $\begin{array}{l}\text { streptomycin } \\
\text { Level of Agent }\end{array}$ & $\begin{array}{r}0 \\
500\end{array}$ & & & $\begin{array}{r}0 \\
500\end{array}$ & & & $\begin{array}{r}0 \\
500\end{array}$ & & \\
\hline $\begin{array}{c}\text { nitrofuran } \# 6 \text { (anti.) } \\
\text { Level of Agent }\end{array}$ & $\begin{array}{r}-2 \\
5 \\
\end{array}$ & $\begin{array}{r}0 \\
15\end{array}$ & $\begin{array}{l}-2 \\
60 \\
\end{array}$ & $\begin{array}{l}0 \\
5\end{array}$ & $\begin{array}{c}-1 \\
15\end{array}$ & $\begin{array}{l}-2 \\
60\end{array}$ & $\begin{array}{l}0 \\
5\end{array}$ & $\begin{array}{r}-2 \\
15\end{array}$ & $\begin{array}{l}-2 \\
60\end{array}$ \\
\hline $\begin{aligned} \text { nitrofuran } & \# 180 \\
\text { Level of } & \text { Agent }\end{aligned}$ & $\begin{array}{l}0 \\
1\end{array}$ & $\begin{array}{l}0 \\
3 \\
\end{array}$ & $\begin{array}{r}-1 \\
5\end{array}$ & $\begin{array}{l}0 \\
1\end{array}$ & $\begin{array}{l}0 \\
3\end{array}$ & $\begin{array}{r}-1 \\
5\end{array}$ & $\begin{array}{r}+1 \\
1\end{array}$ & $\begin{array}{l}0 \\
3 \\
\end{array}$ & $\begin{array}{l}0 \\
5 \\
\end{array}$ \\
\hline $\begin{array}{l}\text { nitrofuran } \#^{246} \\
\text { Level of Agent }\end{array}$ & $\begin{array}{l}0 \\
3\end{array}$ & $\begin{array}{r}+1 \\
9\end{array}$ & $\begin{array}{l}-2 \\
15\end{array}$ & $\begin{array}{l}0 \\
3\end{array}$ & $\begin{array}{l}0 \\
9\end{array}$ & $\begin{array}{r}-2 \\
15\end{array}$ & $\begin{array}{l}0 \\
3\end{array}$ & $\begin{array}{r}-1 \\
9\end{array}$ & $\begin{array}{l}-2 \\
15\end{array}$ \\
\hline $\begin{array}{l}\text { brilliant green dye } \\
\text { Level of Agent }\end{array}$ & $\begin{array}{c}-2 \\
100\end{array}$ & & & $\begin{array}{c}-2 \\
100\end{array}$ & & & $\begin{array}{r}-2 \\
100\end{array}$ & & \\
\hline
\end{tabular}

*O indicates no change as compared to control. Minus $I$ indicates slight depression; Plus 1 indicates slight increase; Minus 2 indicates marked depression; Plus 2 indicates marked stimulation. Significant differences are based on the 95 per cent confidence interval for oxygen consumption, a Chi square value greater than 3.841 for per cent live spermatozoa and a code difference for motility $(<2=+$ or $-1,>2=+$ or -2$)$.

${ }_{* *}^{*} \mu \mathrm{g} . / \mathrm{ml}$. or units $/ \mathrm{ml}$. (Salmotin). 
The question arises whether a stimulation of oxygen consumption is desirable or undesirable. It may be desirable in that it would inclicate an increased activity of the spermatozoa. This does not always seem to be true if motility is a reliable indication of sperm activity. On the other hand, a stimulation would be undesirable if it meant a shorter period of activity. This appears to be true in the data of oxygen consumption for $75 \mu \mathrm{g} . / \mathrm{ml}$. of Panmycin and $15 \mu \mathrm{g} . / \mathrm{ml}$. of nitrofuran $\sharp 6$ (anti.). However, there is not enough evidence at this time to verify this. A depression of oxygen consumption would be desirable only if it meant longer periods of activity, and again, the evidence is insufficient to substantiate this. Therefore, at the present time, it must be assumed that a stimulation or depression is undesirable, and the degree of change must be kept in mind.

Panmycin appears to be undesirable in that there is a significant depression of oxygen consumption and a slight but significant decrease in motility at required levels. The live-dead count does not bear out the toxicity of this agent in that there is no effect at the minimum level and an increase in survival at the $75 \mu \mathrm{g} . / \mathrm{ml}$. level.

Chloromycetin gives a significant depression of oxygen consumption at the $250 \mu \mathrm{g} . / \mathrm{ml}$. level, but the data for motility and live-dead do not indicate an adverse effect. Neomycin sulphate shows a slight stimulation of oxygen consumption that decreases as the concentration increases. There was no effect on motility or per cent live spermatozoa. Salmotin has no effect at the low level, and a slight stimulation at the high level, no effect on motility and a favorable effect on per cent live spermatozoa.

Nitrofuran \#6 (anti.) significantly depresses oxygen consumption at the high and low levels, but exerts no effect at the medium level. Motility and per cent live spermatozoa are adversely affected at the 15 and $50 \mu \mathrm{g} . / \mathrm{ml}$. levels.

Nitrofuran \#180 seems to have no effect at the $1 \mu \mathrm{g} \cdot / \mathrm{ml}$. and 3 $\mu \mathrm{g} . / \mathrm{ml}$. levels on the tested criteria, but a definite toxic effect occurred at the $5 \mu \mathrm{g} . / \mathrm{ml}$. level, as was expected from results of Experiment A.

Nitrofuran \#246 shows a significant stimulation of oxygen consumption, but no effect on motility or live-dead count at the $3 \mu \mathrm{g} . / \mathrm{ml}$. and $9 \mu \mathrm{g} . / \mathrm{ml}$. levels. A concentration of $15 \mu \mathrm{g} / \mathrm{ml}$. is obviously toxic. Brilliant green dye is toxic at a concentration of $100 \mu \mathrm{g} . / \mathrm{ml}$. in that it destroyed the spermatozoa as indicated by all three criteria.

Dihydrostreptomycin and streptomycin sulphate have no effect at the $500 \mu \mathrm{g} . / \mathrm{ml}$. level. 


\section{THE EFFECTS OF ANTIBIOTIC AGENTS ON BOVINE SPERMATOZOA AND VIBRIO FETUS STORED AT $-79^{\circ} \mathrm{C}$.}

Experiment A: Determining the Effect of Antibiotic Agents on the Motility of Spermatozon Stored at $-79^{\circ} \mathrm{C}$.

On the basis of evidence from the first two sections of this study, only five of the sixteen agents were suitable for further study in frozen semen. These five are listed below:

\section{Agents Tested}

dihydrostreptomycin sulphate

neomycin sulphate

nitrofuran compound \#6 (anti.)

nitrofuran compound \#180

nitrofuran compound $\$ 246$
Levels Tested $500 \mu \mathrm{g} . / \mathrm{ml}$. $500 \mu \mathrm{g} \cdot / \mathrm{ml}$.

$5,15 \mu \mathrm{g} . / \mathrm{ml}$.

$1,3 \mu \mathrm{g} . / \mathrm{ml}$.

3, $9 \mu \mathrm{g} . / \mathrm{ml}$.

Two diluters were prepared in freezing the semen. Solution A consisted of $12.0 \mathrm{cc}$. of heated homogenized milk and $0.5 \mathrm{cc}$. of semen. Homogenized milk, obtained from the West Virginia University Dairy, was heated to $93^{\circ} \mathrm{C}$. in a water bath for 20 minutes. The semen was a pooled sample obtained from two Ayrshire bulls of the West Virginia University Dairy Farm. Solution B consisted of 2.5 cc. of glycerol, $1.0 \mathrm{cc}$. of antibiotic solution in sterile KRB, $9.0 \mathrm{cc}$. of heated homogenized milk and four drops of a vegetable dye used for identification purposes. The homogenized milk in Solution A was adjusted to $37^{\circ} \mathrm{C}$. before the semen was added. A control was set up in the same way except that $1.0 \mathrm{cc}$. of sterile $\mathrm{KRB}$ was substituted for the antibiotic solution. The experimental and control flasks of Solution A were allowed to cool to room temperature and then cooled to $5^{\circ} \mathrm{C}$. over a four-hour period. Flasks of Solution $B$ were placed in a refrigerator at $5^{\circ}$ C. at the start of cooling process for flasks of Solution A. At the end of the initial cooling period $\left(5^{\circ}\right.$ C. $)$ Solution $B$ was added to Solution $\mathrm{A}$ in five equal portions at 10 -minute intervals. The mixture of solutions $\mathrm{A}$ and $\mathrm{B}$ was then distributed in $1.5 \mathrm{cc}$. aliquots to Pyrex ampoules and sealed with an oxygen-methane flame. The ampoules of semen were then allowed to equilibrate for 18 hours, and then lowered to $-79^{\circ} \mathrm{G}$. in isopropyl alcohol and dry ice at the rate of $2.2^{\circ} \mathrm{C}$. $/$ minute to $-34.4^{\circ} \mathrm{C}$., then $4.4^{\circ} \mathrm{C}$. $/$ minute to $-79^{\circ} \mathrm{C}$. The diluted frozen semen was stored two weeks and then thawed as needed in a $37^{\circ} \mathrm{C}$. constant temperature water bath.

Thawed semen was then checked for motility and the experimentals compared with controls. An attempt was made to determine oxygen consumption, but it was unsuccessful in that oxygen uptake was not measurable by our techniques. It was concluded that a $50 \mathrm{x}$ dilution 
cubated 96 hours in 7 per cent oxygen at $37^{\circ}$ C. Total plate counts were made at the end of the 48-hour period.

The results of this experiment are shown in Table 6 . Vibrio fetus was recovered from all ampoules of control and experimental groups. Neomycin and dihydrostreptomycin sulphate are undoubtedly the two most effective agents tested in this experiment. Both resulted in a 1,000fold drop of viable recoverable organisms. The three nitrofuran compounds had significant effects on recoverable organisms, but were 10 fold less effective at the high level and 100-fold less effective at the low level than either of the other two agents tested.

Table 6. The Effect of Antibiotic Agents on Vibrio fetus in Bovine SEMEN Stored AT $-79^{\circ}$ C. FOR 14 DAYs

\begin{tabular}{|c|c|c|c|c|}
\hline TREATMENT & $\begin{array}{l}\text { LeVEL } \\
\mu \mathrm{g} . / \mathrm{ml} \text {. }\end{array}$ & $\begin{array}{c}\text { No. OF ORGanisms } \\
\text { RECOVERED }\end{array} \mid$ & $\begin{array}{l}\text { LEVEL } \\
\mu \mathrm{g} . / \mathrm{ml} \text {. }\end{array}$ & $\begin{array}{c}\text { No. OF ORGanisms } \\
\text { RECOVERED }\end{array}$ \\
\hline $\begin{array}{l}\text { Control } \\
\text { dihydrostreptomycin } \\
\text { sulphate } \\
\text { neomycin sulphate } \\
\text { nitrofuran } \# 6 \text { (anti.) } \\
\text { nitrofuran } \# 180 \\
\text { nitrofuran } \# 246\end{array}$ & $\begin{array}{r}500 \\
500 \\
5 \\
1 \\
3\end{array}$ & $\begin{array}{l}5 \times 10^{6} \\
3-10 \times 10^{3} \\
3-10 \times 10^{3} \\
4-10 \times 10^{5} \\
4-10 \times 10^{5} \\
4-10 \times 10^{5}\end{array}$ & $\begin{array}{r}15 \\
3 \\
9\end{array}$ & $\begin{array}{l}4-10 \times 10^{4} \\
4-10 \times 10^{4} \\
4-10 \times 10^{4}\end{array}$ \\
\hline
\end{tabular}

Bovine semen was inoculated with approximately $5 \times 10^{\top}$ organisms $/ \mathrm{ml}$.

\section{Conclusion}

The results of this series of experiments indicate that of the 16 agents tested only neomycin sulphate, dihydrostreptomycin sulphate, and nitrofurans \#180 and \#246 are suitable for use in frozen semen. Neomycin sulphate and dihydrostreptomycin sulphate were found to be equal in effectiveness, and superior to either of the nitrofuran compounds. The third nitrofuran compound, \#6 (anti.), was equal to \#180 and \#246 in effectiveness against Vibrio fetus, but reduced the motility of spermatozoa. Optimum levels are $500 \mu \mathrm{g} \cdot / \mathrm{ml}$. for neomycin sulphate and dihyclrostreptomycin sulphate, and 3 and $9 \mu \mathrm{g} . / \mathrm{ml}$. respectively for nitrofurans \#180 and \#246.

It can be concluded that none of the agents tested will destroy Vibrio fetus in frozen semen employing the present techniques, but use of dihydrostreptomycin sulphate and neomycin sulphate did result in a significant reduction in the number of organisms present. This justifies their use in frozen semen.

A comparison of results of Experiment B, Section I, "Determination of Bactericidal Effects," and Experiment B, Section III, "The Effects of Antibiotics on Vibrio fetus in Frozen Semen," inclicates two things 
may have happened: (1) antibiotic agents may be less effective against Vibrio fetus for 18 hours exposure at $5^{\circ}$ C. than for 12 hours exposure at $37^{\circ} \mathrm{C}$. in neomycin sulphate and 18 hours exposure at $37^{\circ} \mathrm{C}$. for the other agents; and (2) glycerol, the only additional agent added to frozen semen, may be interfering with the interaction of antibiotic and organism.

\section{Literature Cited}

1. Almquist, J. O., W. T. S. Thorp, and C. D. Knodt, "The Effect of Penicillin Upon the Livability, Glycolysis, and Bacterial Content of Bovine Semen." J. Dairy Sci., 31:11-19 (1948).

2. Almquist, J. O., P. J. Glantz, and W. T. S. Thorp, "The Effect of Streptomycin Upon the Livability, Glycolysis, and Bacterial Content of Bovine Semen." J. Dairy Sci., 31:501-507 (1948).

3. DiLullo, L. K., L. T. Poelma, and J. E. Faber, "The Effect of Antibiotics on Vibrio Fetus and Bovine Spermatozoa." Am. J. Vet. Research, 18:86-92 (1957).

4. Dunn, H. O., "The Effect of Freezing Bovine Spermatozoa in Extenders Containing Antibacterial Agents." J. Dairy Sci. 36:728-732 (1953).

5. Easterbrooks, H. L. and W. N. Plastridge, "Experimental Transmission of Vibrio Fetus in Diluted Semen by Contact." Am. Vet. Med. Assn. J., 120:199-201 (1952).

6. Erickson, W. E., E. F. Graham, and E. C. Fredrick, "The Effect of Antibiotics, Levels of Glycerol and Rates of Freezing on Revival Rate of Bovine Spermatozoa in Yolk Citrate and Milk Extenders." J. Dairy Sci., 37:651 (1954).

7. Foote, R. H. and R. W. Bratton, "Motility of Spermatozoa and Control of Bacteria in Bovine Semen Extenders Containing Sulfanilamides, Polymyxin and Aureomycin." J. Dairy Sci., 33:545-547 (1950).

8. Hughes, D. E. and H. L. Gilman, unpublished data. New York State Veterinary College, Ithaca, N. Y. 1954-1956.

9. Jones, W. M., J. R. Perkins, and D. M. Seath, "The Effect of Glycerol Level and Rate of Freezing for Various Extenders on the Survival of Bovine Spermatozoa Frozen and Stored at $-79^{\circ}$ C." J. Dairy Sci., 39:1974 (1956).

10. MacPherson, J. W. and N. A. Fish, "The Survival of Pathogenic Bacteria in Bovine Semen Preserved by Freezing." Am. J. Vet. Research, 15:548-550 (1954).

11. O'Dell, W. T. and J. O. Almquist, "Techniques for Freezing Bull Spermatozoa in Heated Milk, and Preliminary Breeding Results." J. Dairy Sci., 37:652 (1954).

12. Orthey, A. E. and H. L. Gilman, "The Antibacterial Action of Penicillin, Streptomycin and Sulfanilamide Against Heavy Suspensions of Vibrio Fetus Added to Semen Extenders." J. Dairy Sci., 37:407-417 (1954).

13. -__-, "The Antibacterial Action of Penicillin and Streptomycin Against Vibrio Fetus Including Concentrations Found in Naturally Infected Semen." J. Dairy Sci., 37:416-424 (1954).

14. Plastridge, W. N. and H. L. Easterbrooks, "The Effect of Antibiotics in Diluted Bull Semen on Vibrio Fetus." Am. J. Vet. Research, 13:145-148 (1952).

15. Prier, J. E., "The In Vitro Effect of Several Antibiotics Against Vibrio Fetus." Veterinary Medicine, 46:350-359 (1951).

16. Sykes, J. G. and J. B. Mixner, "Toxicity of Bull Spermatozoa of Various Salts, Brands and Lots of Penicillin, Streptonycin, Aureomycin, and Chloromycetin." J. Dairy Sci., 34:342-346 (1951).

17. Stegenga, T. H., Vibrio Fetus En Enzootische Sterileteit." Tiddscher Diergeneesk, 75:753-763 (1950).

18. Terpstra, L. L., La Sterilite des Bouides D'Origine Microbienne. Office International Des Epizoories, Report 19, pp. 1-16, 1951. 


\section{APPENDIX}

\section{Manufacturers of Antibiotics Used in This Study}

Abbott Laboratories .................. North Chicago, Ill. Salmotin (synnematine)

Charles Pfizer and Company .............. New York, N. Y. Aureomycin (chlortetracycline)

Terramycin (oxytetracycline)

streptomycin sulphate

E. R. Squibb and Sons ................ New Brunswick, N. J. thiostrepton amorph.

Merck and Company ................... Rahway, N. J. veterinary neomycin sulphate dihydrostreptomycin sulphate oxamycin (calcium)

Cathonycin (NA novobiocin)

National Analine Division, Allied Chemical and Dye Co.

brilliant green dye

Norwich Pharmacal Company .............. Norwich, N. Y. nitrofuran $\# 6$ (anti.) 604-106

nitrofuran \#180 311-5tl

nitrofuran \#246 515s-34bc

Parke, Davis and Company ............... Detroit, Mich. veterinary Chloromycetin ( $\mathrm{HCl}$ )

Sharpe and Dome ...................West Point, Pa. neomycin sulphate

Upjohn Company .................... Kalamazoo, Mich.

Panmycin (tetracycline hydrochloride)

streptomycin sulphate

bacitracin 



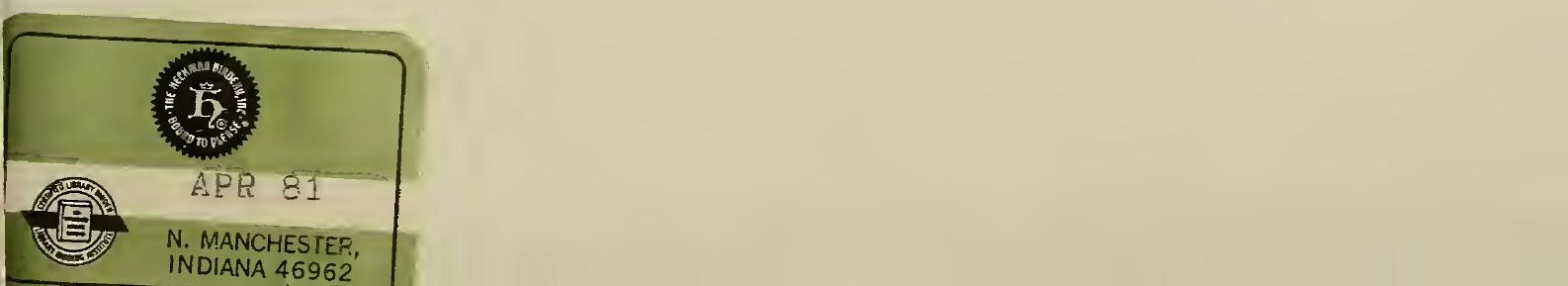


